\title{
Semi-solid processing of tool steel
}

\author{
P. KAPRANOS, D.H. KIRKWOOD and C.M. SELLARS
}

The University of Sheffield, Department of Engineering Materials, P.O. Box 600, Sir Robert Hadfield Bldg., Mappin Street, Sheffield S1 4DU, England

\section{$\underline{\text { Abstract }}$}

Semi-solid processing (SSP) of alloys has been used commercially since the early eighties for the manufacture of components in the automobile and aerospace industries. The thrust of the early development has been in aluminium and copper alloys. The nature of the process makes it an ideal candidate for the manufacture of components in alloys which are either difficult or virtually impossible to forge by conventional means. Alloys such as tool steels, stellites and superalloys, offer the possibility of lucrative niche for commercial exploitation.

The work described in this paper is the result of three years of development in the semi-solid processing of high melting point alloys. The development of the appropriate microstructures for thixoforming M2 tool steel (both through Spray Formed and Recrystallisation and Partial Melting (RAP) routes) is examined and discussed. The thixoforming of $\mathrm{M} 2$ tool steel in non-metallic dies is described in some detail, together with the way process parameters appear to affeet the structure and properties of the final product. The resulting microstructures are closely examined and presented with values of mechanical properties in the as forged and heat treated conditions.

\section{Introduction}

Semi-solid processing of alloys originated at the MIT Materials Engineering laboratories in the early 70's $(1,2)$. Since then it has progressed from a laboratory curiosity, to a fully commercial process for the production of near net shape components in a variety of materials and for a diverse industrial clientele $\mathrm{e}^{(3,4,5)}$. The main thrust of commercial development has taken place in the use of aluminium alloys, and to a lesser extent copper and magnesium alloys ${ }^{(4,5)}$. However the ability of the process to shape almost any alloy to a near net shape product in a single operation, provides it with tremendous advantages over its competitors. The advantages are accentuated when shaping high melting point alloys such as tool steels, stellites and superalloys which are either difficult or nearly impossible to shape using conventional methods.

Work carried out at Sheffield ${ }^{(6)}$ has established the feasibility of shaping high melting point alloys by thixoforging, one variant of semi-solid processing (SSP). Currently work is organised around the optimisation of process parameters for M2 tool steels and stellite 21 and the assessment of mechanical properties and microstructures of the resulting products.

The key to the SSP of alloys lies in the unique microstructures of the feedstock materials in which the solid particles are spheroidal in shape as opposed to the typical dendritic microstructures of cast alloys. 
A number of ways are available for producing the necessary microstructures for SSP, as published in the literature or in patents $\mathrm{s}^{(7,8,9,10,11,12)}$.

In this work, two distinctly different routes were used in producing the feedstock :

- Recrystallisation and Partial Melting (RAP), and

- Spray Forming (Osprey).

In the RAP process, also known under the acronym SIMA (Strain Induced Melt Activated), conventionally produced material undergoes heavy deformation. When it is heated up so that recrystallisation takes place before partial melting, liquid penetration at grain boundaries leads to fine $(30 \mu \mathrm{m})$ non-dendritic speroidal microstructures ${ }^{(13,14)}$.

In spray forming, a stream of liquid metal is atomised by a gas jet and deposited on to a target at high velocities. The droplets, of different sizes, arrive at the target at different temperatures and states of solidification (Figure 1). Under optimum conditions, the coarser particles are deposited in the fully molten state, the finer ones are fully solidified at a temperature close to that of the atomising gas, and the majority are deposited in the semi-solid condition or in an undercooled state. The high impact velocities involved, result in dendrite fragmentation in particles that have partially solidified during flight. As a result, the final microstructures are non-dendritic with fine grain size $(20 \mu \mathrm{m})$ and are amenable to SSP.

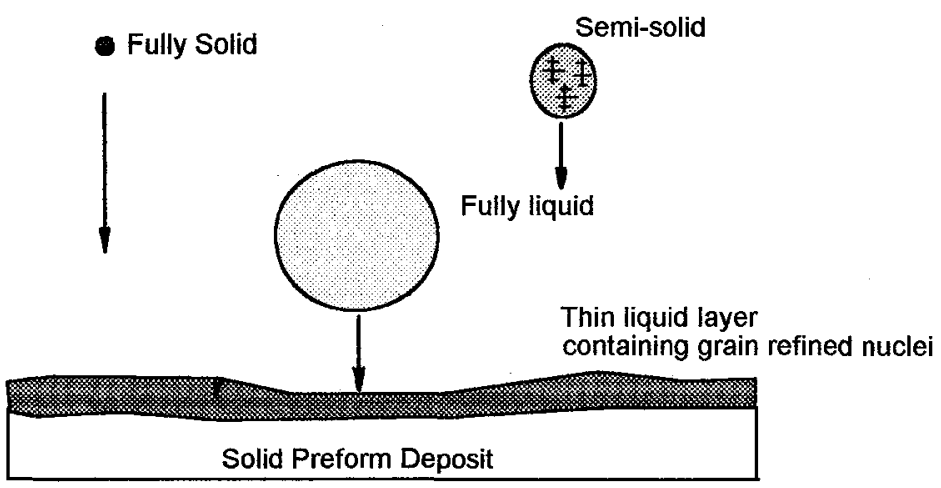

Figure 1. Schematic representation of the Spray-forming process.

\section{SSP at Sheffield}

\subsection{The Process}

Presently, in the commercial versions of SSP, the process is highly automated and parts are produced for military, aerospace, automotive and other high quality and safety critical applications. The bulk of commercial interest though is in high integrity aluminium components and MMC's, especially for the automotive industry.

The Sheffield process consists essentially of two operations:

- the partial melting of a slug to the semi-solid state to produce a uniform non-dendritic microstructure of the correct softness, and

- its rapid transfer and injection into a closed die.

The heating of the slug, which is placed on a ceramic pedestal that forms part of the ram of the thixoforging press, is carried out within a vacuum/controlled atmosphere chamber in an induction furnace. Once the correct softness of the slug is attained, it is automatically forged into the die cavity by the action of the ram. The press has the capacity of producing a $100 \mathrm{kN}$ load during forging and is able 
to transfer a slug of material to be injected into the die at a maximum velocity of $1.5 \mathrm{~m} / \mathrm{s}$. The press is computer controlled allowing the operator to select :

- the speed of transfer of slug into the die,

- the velocity of the ram during the slug injection, and

- the final load during consolidation of the slug and its time of application.

The dies used for the thixoforging of high melting point alloys were made of graphite. Currently work is being carried out on the development of composite non-metallic dies. Such dies could be employed because of the low stresses involved during SSP of material in the correct semi-solid state. Typically, stresses of $<1 \mathrm{MPa}$ are encountered in thixoforging of $\mathrm{M} 2$ tool steel, as compared with $>100 \mathrm{MPa}$ for hot forging.

\subsection{Thixoforging of M2 tool steel}

As outlined earlier, the M2 tool steel to be thixoforged was produced by the RAP and spray forming routes. In order to gain an insight into the microstructural development of this alloy when in the semi-solid state, a series of heating experiments was carried out in which small coupons of M2 alloy produced by both routes were heated at different temperatures within the semi-solid region and held isothermally for various time intervals. These experiments were very informative in establishing relationships of fraction liquid with temperature, and grain size with holding time at a given temperature, as shown in Figure 2. It was also demonstrated that the resulting microstructures from the two routes were very similar in grain size and morphology, Figure 3.

Fraxtion Liquid $(\%)$

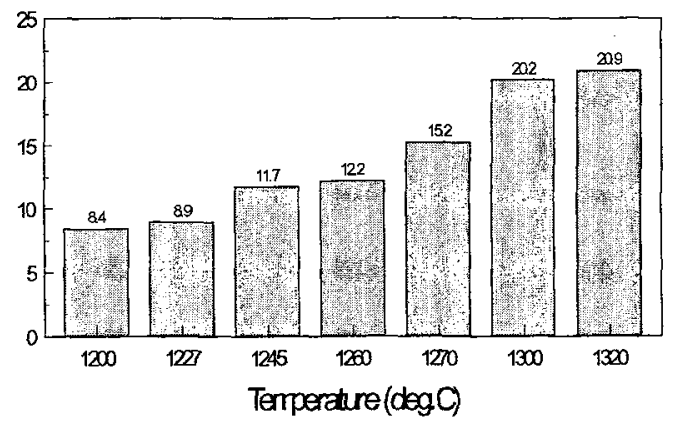

Gain $\$ x(\mu m)$
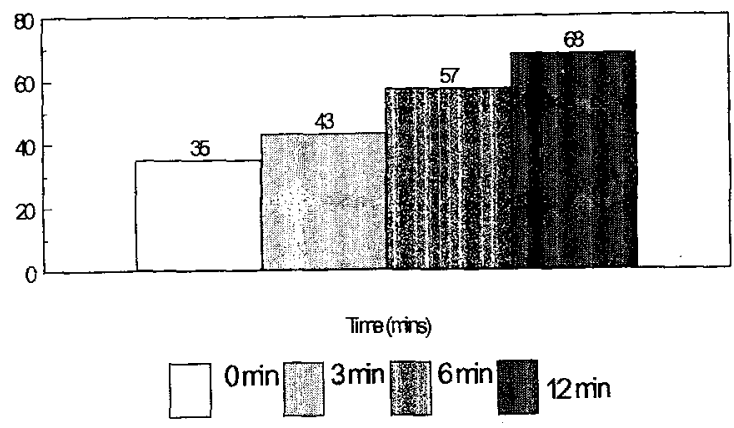

(a) RAP

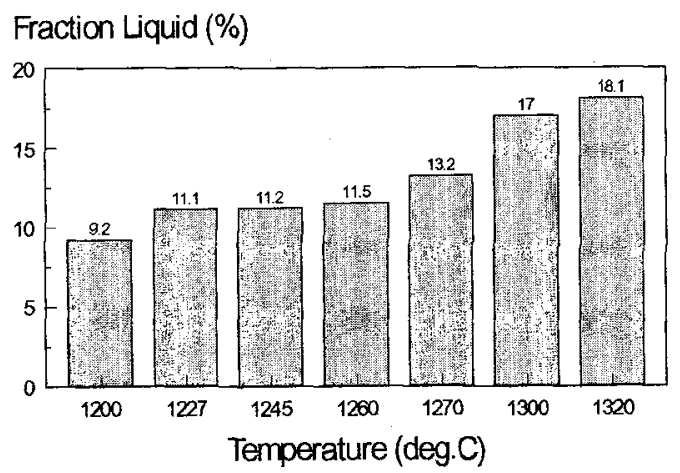

Grain Size $(\mu \mathrm{m})$
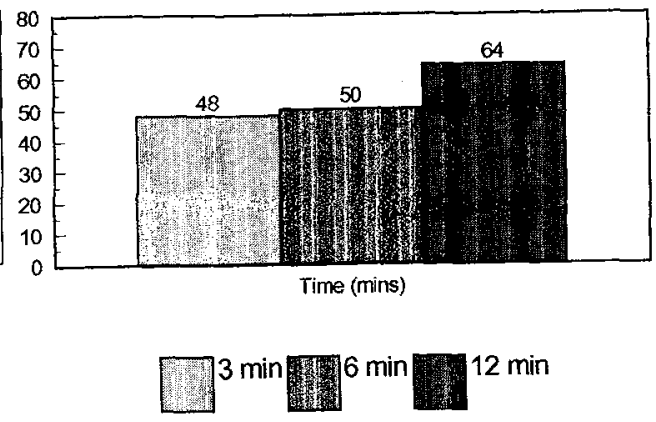

(b) Spray forming

Figure 2. Variation of (i) fraction liquid with temperature and (ii) grain size with holding time for M2 tool steel. 


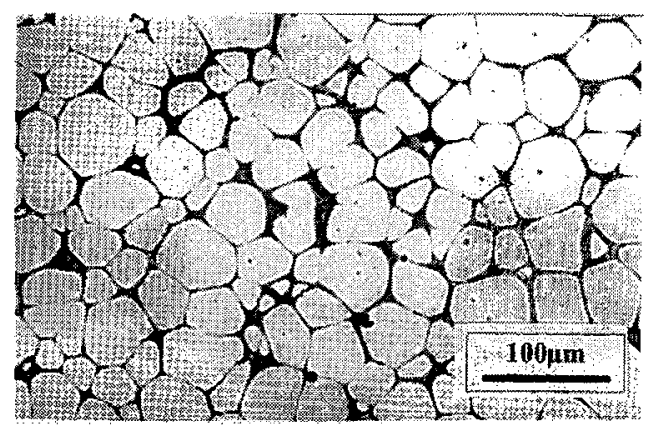

(a) RAP

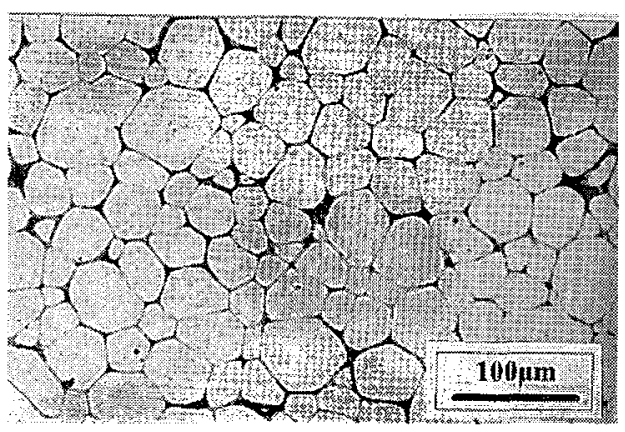

(b) Spray forming

Figure 3. Microstructures of $\mathrm{M} 2$ tool steel coupons held isothermally at $1300^{\circ} \mathrm{C}$ for 12 minutes.

In order to assess the mechanical properties of thixoforged M2 tool steel, graphite dies were used to produce finger-like forgings of $60 \mathrm{~mm}$ length and $6 \mathrm{~mm} \times 19 \mathrm{~mm} \times$ section, which could be machined into specimens for tensile testing. The tensile strength (TS) and hardness values are given in Table 1. Figure 4. shows the microstructure of a typical thixoforged M2 tool steel product in the as forged condition. Figure 5. shows the carbide morphology in the as forged and tempered conditions. The microstructures of the as-forged $\mathrm{M} 2$ tool steel consisted of fine and reasonably uniform grains of around 40-50 $\mu \mathrm{m}$ diameter, surrounded by a network of eutectic structure and acicular carbides. This carbide morphology responded to heat treatment at $1220^{\circ} \mathrm{C}$ by speroidising into discrete carbide particles as shown in Figure 5. The steel was hardened and tempered at $580^{\circ} \mathrm{C}$ for $1 \frac{1 / 2}{2}$ hours to produce the hardness values shown in table 1 . The observed porosity has been centreline and consistantly below $1 \%$.

Table 1. Properties of thixoforged M2 tool steels.

\begin{tabular}{|l|l|l|}
\hline Material & TS (MPa) & Hardness (HV) \\
\hline M2 (RAP) thixoforged in air & 451 & \\
\hline M2 (Spray formed) in air & 605 & \\
\hline M2 (RAP) in $\mathrm{N}_{2}+5 \% \mathrm{H}_{2}$ shroud & 543 & \\
\hline M2 (RAP) in vacuum & 1,214 & \\
\hline M2 (RAP) as received & & 280 \\
\hline Austenitised & & 835 \\
\hline Tempered & & 810 \\
\hline Overtempered & & 690 \\
\hline M2 (RAP) as thixoforged: & & 680 \\
\hline Austenitised & & 860 \\
\hline Tempered & & 840 \\
\hline Overtempered & & 650 \\
\hline
\end{tabular}

Presently, work is concentrated on optimising the process parameters when thixoforging the steels produced by the two different routes discussed above. The parameters under investigation are injection velocity, forging load, dwell time, and fraction liquid content. A number of tests are planned for assessing the quality of the final products, including bend tests, hardness, density, porosity and toughness measurements. 

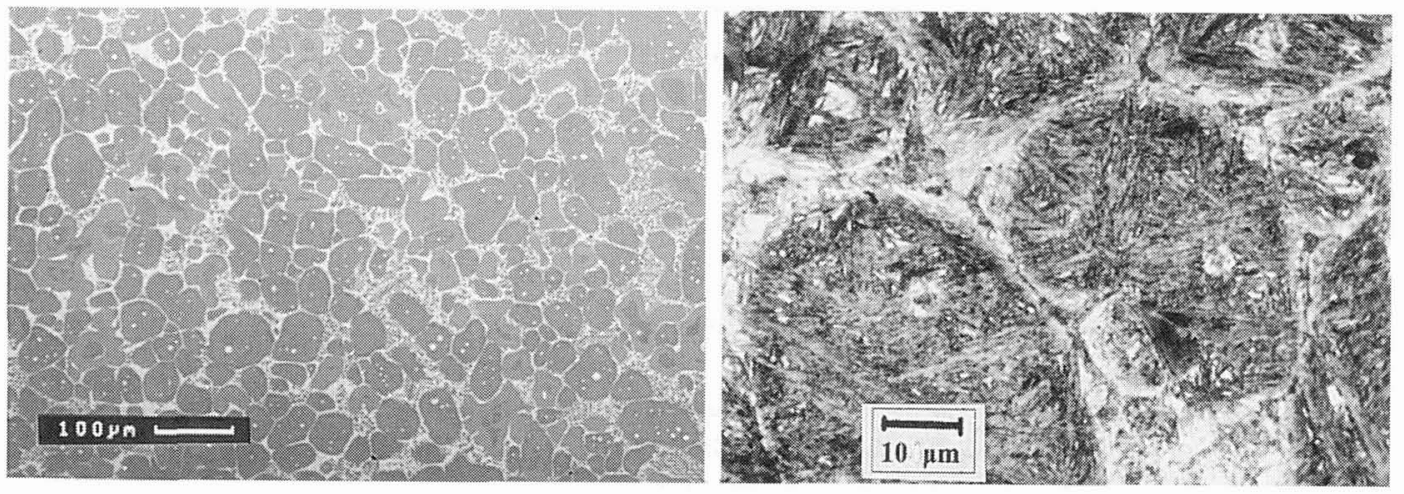

Figure 4. Microstructures of thixoforged M2 tool steel.
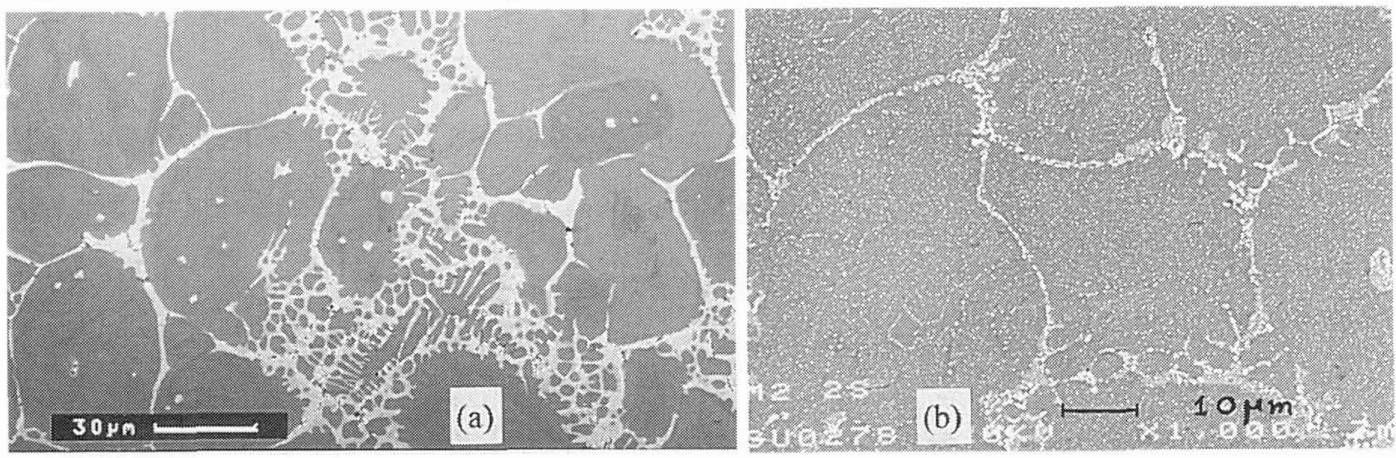

Figure 5. Carbide morphology of M2 tool steel (a) as thixoforged and (b) after austenitising at $1220^{\circ} \mathrm{C}$, quenching and tempering at $580^{\circ} \mathrm{C}$ for $1 \frac{1 / 2}{2}$ hours.

As a final demonstration of the potential in thixoforging high temperature alloys, a number of toothed cog wheels have been thixoforged from M2 (RAP) tool steel stock, see Figure 6. As can be seen from the figure, these articles have been reproduced with a high degree of accuracy in both shape and surface detail. The surface is essentially bright and free from oxide scale, although in some places the appearance is marred by the presence of an insulation blanket used as a temporary measure to obtain more uniform heating in the induction furnace. It is clear that complex shapes such as gears and cutting tools can be manufactured with good surface finish and properties in high speed tool steels, using thixoforging technology and comparatively cheap starting material.

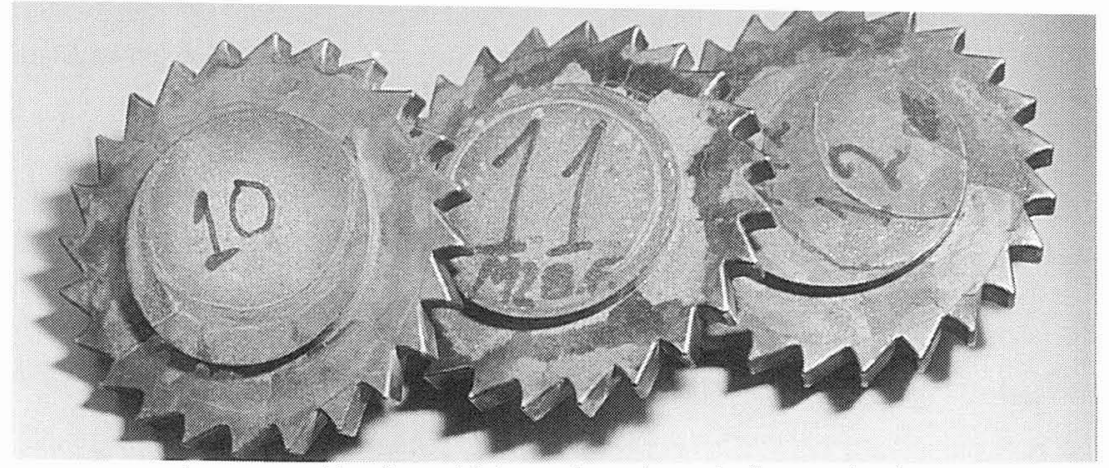

Figure 6. Thixoforged M2 tool steel toothed cog whesl. 


\section{Conclusions}

The ability to produce near net shape products in high melting point alloys via semi-solid processing has been clearly demonstrated. The viability of two distinct production routes for the starting material has also been established. Some values of mechanical properties have been obtained, but the current work aims to optimise the thixoforging process and produce data bases of properties for high melting point alloys produced via semi-solid processing routes.

\section{Acknowledgements}

The authors express their sincere thanks to the sponsors of this work: The ACME Directorate of SERC and the Thixoforging Club members ${ }^{(*)}$ for their financial support throughout this work.

Thanks are also given to Mr.TF Cockrell for his dedication and contribution to the day to day running of the work, and to Dr.PJ Ward for helpful discussions.

${ }^{(* *)}$ Amax Inc., Barworth Flockton Ltd., Deloro Stellite Ltd., EA Technology, GKN, Lucas Engineering and Systems Ltd., Osprey Metals Ltd., Rolls Royce plc., Thornton Precision Forgings Ltd., and United Engineering and Forging Ltd.

\section{References}

1. SPENCER D.B., Mehrabian R., and Flemings MC, Metall. Trans., (1972), 3, 1925-1932.

2. JOLY PA, and Mehrabian R, J. Mater. Sci., (1976), 11, 1393- 1418.

3. KENNEY MP et al., Metals Handbook, 9th edition, Vol. 15, (19)88, 327-338 (ASM Int., Metals Park, Ohio).

4. MOSCHINI $R$ 2nd Int.Conf. on SSP of Alloys and Composites, June 10-12, (1992), MIT, Cambridge, Mass., USA, 149-158.

5. PASTERNAK L, et al, 2nd Int. Conf. on SSP of Alloys and Composites, June 10-12 (1992), MIT, Cambridge, Mass., USA, 159-169.

6. KAPRANOS P, Kirkwood DH and Sellars, CM, J. of Engineering Manufacture, B1a, Vol.207, April (1993), 1-8.

7. LEATHAM A et al., Osprey Process, Metals and Materials, March (1989), 5 (3), 140-143.

8. ABIS S, 2nd Int. Conf., on Semi-Solid Processing of Alloys and Composites, June 10-12, (1992), MIT, Cambridge, Mass., USA.

9. GABATHULER JP et al, 2nd Int. Conf. on SSP of Alloys and Comp., June 10-12, 1992, MIT, Cambridge, Mass., USA, 33-46.

10. KIRKWOOD DH et al., US Patent No.: 5,133,811, Jul. 28, (1992).

11. YOUNG KP, US Patent No: $4,687,042$, Aug.18, (1987).

12. ITO Y. et al, Proc. Symp. on Nature and Properties of Semi-Solid Materials, San Diego, Calif. March 1-5, (1992), Publ. TMS, 3-17.

13. ROBERT MH and Kirkwood DH, Proceedings of Int. Conf. on Solidification Processing, (1988), 405-408, (The Institute of Metals).

14. KAPRANOS P, Kirkwood DH, and Sellars CM, 1st European Conf. on Advanced Materials and Processes, Aachen, Germany, (1990), Proceedings Publ. DGM, Vol. 1, 165-170. 